\title{
Decision-Making Rationales among Quebec VET Student Aged 25 and Older
}

\author{
Louis Cournoyer*1 and Frédéric Deschenaux ${ }^{2}$ \\ ${ }^{1}$ Université du Québec à Montréal 1205, rue Saint-Denis, N-4900 Montréal (Québec), Canada \\ ${ }^{2}$ Université du Québec à Rimouski 300, allée des Ursulines, C.P. 3300, succ. A Rimouski \\ (Québec), Canada
}

Received: 30.03.2017; Accepted: 11.09.2017; Published: 22.11.2017

\begin{abstract}
Each year, a large number of students aged 25 years and over take part in vocational and education training (VET) programs in the Province of Quebec, Canada. The life experiences of many of these adults are marked by complex psychosocial and professional events, which may have influenced their career decision-making processes. This paper aimed to identify key rationales guiding the decisions of adults aged 25 years and older to return to education based on a thematic analysis of 30 semi-structured interviews with students enrolled in a VET program. The analysis focused on two theoretical axes: one biographical and the other interactionist. The first involved personal life courses and professional projects undertaken by the student in the past. The second examined tensions and conflicts between context forces and adjustment strategies adopted by the student. The results revealed five decision-making rationales that characterized the vast majority of the students' experiences: 1) get out of a socioprofessional and economic slump; 2) know yourself better, personally and socially; 3) value the concrete and the practical; 4) take advantage of supporting conditions; and 5) reconcile proximity and the known. The relevance and implications of these findings for professionals and decision makers in vocational training are discussed.
\end{abstract}

Keywords: VET, Vocational Education and Training, Vocational Training, Adults, Decision-Making, Qualitative, Life-Course

*Corresponding author: cournoyer.louis@uqam.ca

ISSN: $2197-8646$

http://www.ijrvet.net 


\section{Introduction}

Vocational Education and Training (VET) is an educational system that favours professional qualification and access to employment for the greatest number of people (Fournier, Lachance, \& Bujold, 2009; Organisation for Economic Co-operation and Development, 2010). From one country to another, vocational education and training models may vary considerably. International distinctions observed (Bosch \& Charest, 2008; Brockmann, Clarke, \& Winch, 2008) suggest a preference for continuous alternation between formal education and that of the workplace for countries such as Germany, Austria, Switzerland, Denmark or Norway, while for other countries including Canada, the United States, England or France, a sequential approach between school and employment is prioritized. In Canada, VET is offered to secondary and college levels in the form of vocational and technical training programs lasting from one to four years. Quebec, one of Canada's provinces whose population is mainly French-speaking, offers over 200 programs leading to a diploma of vocational studies (DVS). These programs are of a duration of 600 to 1800 hours, accessible from the ninth, tenth or eleventh year of education (Ministère de l'éducation, du loisir et du sport du Quebec, 2010; Molgat, Deschenaux, \& LeBlanc, 2011). Quebec's VET programs attract 142,000 students (Ministère de l'éducation, de l'enseignement et de la recherche du Quebec, 2015), threequarters of whom are age 20 and over (MEERQ, 2015), half over 25 and a third over 30 (MELS, 2007; 2010). In comparison, $85 \%$ of students enrolled in advanced studies in a college technical program are younger than 25 (MELS, 2010). Women (46\%) are almost as numerous as men (54\%) (MELS, 2010). Five objectives guide VET educative services in Quebec: 1) increasing an individual's autonomy, 2) facilitating social and professional integration, 3) promoting access to and retention in the labour market, 4) contributing to the economic, social and cultural development of one's environment and (5) acquiring an accredited diploma (Government of Quebec, 2017).

VET is not often the first choice of education at the end of secondary school, but in the long run, one third of a generation obtains a VET diploma. It has long had an aura of unfavourable prejudice (Lehmann, Taylor, \& Wright, 2014; MELS/Réseau des commissions scolaires, 2007). The social discourse advanced by various parties concerning youth (close and extended family, media and general public, even some teachers and educational professionals), conveys the idea that VET does not seem as interesting as higher education in their eyes (Conseil supérieur de l'Éducation, 2012; Cournoyer \& Lachance, 2014; Krahn \& Taylor, 2005; MELS, 2007). Over the past 20 years, most Quebec public education policies (MEQ, 1997, 2002; MELS, 2009; MEERQ, 2017) have proposed or endorsed intense efforts to promote vocational education and training among young people under age 20, though the student body is increasingly composed of older adults (Hart, 2017). Although college and university studies remain appealing to a large proportion of adults in training of all ages, it seems surprising that such a large number of young people over age 25 are enrolled in vocational education and training. By examining typical educational paths, you might expect that the vast majority of students have completed their studies by age 25. Indeed, graduation from secondary school occurs around age 17 . Pre-university college studies take two years and undergraduate programs are expected 
to take three or four full-time years to complete, leading to a bachelor's degree around age 22. Therefore, at age 25, a student following a linear path without interruption may reasonably expect to have a master's degree. According to Goyer (2017), the repeated failures of Quebec educational policies result from a failure to take into account that the current average age of students in vocational education and training is 27 years old. These students' life paths and professional experiences are varied and atypical, compared to those of general education students. Apart from the presence of a pedagogical regime in place since 1988 within the Education Act (Government of Quebec, 1988), there is no real national policy to promote vocational education and training for all groups of populations in Quebec.

Vocational education and training students have highly heterogeneous profiles, ranging from general to secondary education graduates to social benefit or employment insurance recipients, whose training was funded by governmental services. These adults - workers or people in career transition, mothers of single-parent families, or newcomers who want to improve their living conditions - find themselves more or less obligated to reorient themselves (Deschenaux \& Roussel, 2010). More than any other educational level, a significant number of students have experienced and sometimes still experience academic, social, professional, familial, psychological or other difficulties (Lehman, Taylor, \& Wright, 2014; Vonthron, Lagabrielle, \& Pouchard, 2007). As people advance into adulthood, it can become harder to go back to school for a variety of reasons, including doubts about one's academic abilities, fears of reviving painful memories, difficulties reconciling work-family-study conflicts, problems with finance planning, registration procedures and documents, insufficient institutional psychological support, and negative perceptions of school (d'Ortun, 2009; Goyer, Landry, \& Leclerc, 2008).

Lifelong vocational guidance and training are linked to an ongoing process of identity building, socialization and socioprofessional integration (Aubret \& Demouge, 2007). Adults over age 25 are more likely to deal with more complex psychosocial realities in career decision-making because of the plurality of events and contexts that make up their life paths (Boutinet, 2004; Patton \& McMahon, 2006; Peavy, 1997; Savickas et al., 2009). Since Quebec VET programs have attracted more adult students in recent decades, it is important to understand the logic guiding their career decision to return to school in VET.

\section{Conceptual Framework}

Making a career decision is a complex process that varies among individuals, involving cognitive, emotional, behavioural, relational and contextual issues (Hodkinson \& Sparkes, 1997; Lent, Brown, \& Hackett, 1994; Patton \& McMahon, 2006; Peterson, Sampson, Reardon, \& Lenz, 2002; Saka \& Gati, 2007). In addition, these decisions imply a share of historicity and self-projection, as well as a quest for freedom from constraints and contextual barriers (Berthoz, 2013). Over the past few decades, some researchers (Lent, Brown, \& Hackett, 1994; Patton \& McMahon, 2006; Peterson, Sampson, Lenz, \& Reardon, 2002; Saka \& Gati, 2007) have taken an interest in better understanding the 
optimization of the fit between a person's individual characteristics and that of their living environment in the context of career decision-making. In this regard, career decisions are based on representations of self (interests, values, aptitudes, personality traits) and the world (study programs, professions, job market), goals, obstacles and timeframes, ways of gathering and processing information (Beaucher \& Mazalon, 2003), relationships to others, institutions and other social structures (Blesson, 2001; Boutinet, 2005; Doray, Bélanger, \& Mason, 2005), as well as professional projects superimposed on each other (Lhotellier, 2003; Valach, Young, \& Michel, 2003). For more experienced workers, needs for security and stability, especially attached to job insecurity or socioeconomic exclusion (Bujold \& Fournier, 2008), can sometimes impose themselves and weigh more heavily on individual actions than the actualization of interests and personal resources (Cournoyer, Fortier, \& Deschenaux, 2017).

Research led by Gati, Krausz and Osipow (1996) and by Gati, Landman, Davidovitch, Asulin-Peretz and Gadassi (2010) on career decision-making processes suggests paying attention to levels of preparedness (motivation, indecision, dysfunctional beliefs), information (on self, occupations, the process, information gathering), representations (internal or external conflicts, unreliable information) and sociorelational influences. Some researchers advance the notion of non-linear paths within which career decisions are constructed and operate (Patton \& McMahon, 2006; Peterson, Krumboltz, \& Garmon, 2005; Savickas et al., 2009; Bessin, Bidart, \& Grossetti, 2010) and of the influence of sociorelational contexts (Peavy, 1997; Vondracek \& Reitzle, 1998).

In this study, analysis of the rationales guiding Quebec adults age 25 and over committed to continuing education in VET is based on the decision-making model inspired by the works of Cournoyer, Lachance and Samson (2016) and by Cournoyer, Fortier and Deschenaux (2017). This modeling proposes an analysis of career decision-making from two interdependent perspectives, one of a biographical nature - between life path and professional project (Bertaux, 2005; Boutinet, 2005; Niewiadomski \& Delory-Momberger, 2013; Shanahan, 2000), and the other of a human agency nature - between contextual forces and adjustment strategies (Elder, 1998; Lahire, 2001).

The biographical perspective rests on the continuous tension between life path and professional project. As Elder points out (1998), life paths are shaped by the historical times and places encountered, emerging conjunctures, interrelated individual lives and by the unique agency of each person, i.e. actions taken in relation to a singular universe of possibilities. All the events, transitions and encounters experienced, as well as the times and places where they occur, contribute to the configuration of a universe of possibilities and limitations specific to each person (Charbonneau, 2005; De Coninck \& Godard, 1991; Shanahan, 2000). In addition to dealing with the resources and barriers - real or perceived - on their path, what characterizes every human being is their ability to project themselves into the future based on knowledge acquired from the past to the present, to give meaning and a future representation to their existence (Bart \& Fournet, 2010; Boutinet, 2005).

The interactionist perspective is based on the continuous tension between contextual forces and adjustment strategies with regard to the evolution of life paths and professional projects that shape them and are shaped by them. Many contextual forces bearing 
positively or negatively on a person are inaccessible to the conscience (Bourdieu, 1994; Hodkinson \& Sparkes, 1997; Lahire, 2001). They are the product of standards, values, guidelines, ideologies, instructions, injunctions, structures, etc. that condition individual action (Cacouault \& Oeuvrard, 2001; Dumora, Aisenson, Aisenson, Cohen-Scali, \& Pouyaud, 2008). A person's social networks are also part of these contextual forces (Bourdon, Charbonneau, Cournoyer, \& Lapostolle, 2011; Bidart, Lavenu, \& Pélissier, 2005; Degenne \& Lebeaux, 2004), of relational, institutional and social systems (Bronfenbrenner, 1977, 1986; Deschenaux \& Laflamme, 2009; Bourdieu, 1980) and they operate especially through groups to which one belongs (Coslin, 2002; Grote \& Hall, 2013). Within social structures and networks, various forms of support (information, counseling, encouragement, feedback, etc.) also put pressure - positively and negatively - on decision-making conduct, particularly career decision-making (Burt, 2000; Cournoyer, 2012; Giordano, 2003; Granovetter, 1973).

As for adjustment strategies, they consist of actions employed in order to integrate contextual forces with individual approaches, projects or designs throughout the course of one's life. In a career decision-making context, adjustment strategies may consist of information gathering and processing about oneself in interaction with the world, search for support, counsel and opinions, attitudes and behaviours implemented to adapt to somewhat stressful or anxiety-producing situations, etc. (Dupuy, 1998; Lent, Brown, \& Hackett, 2000; Savickas, 1999). Over the course of one's life and with regard to the quest for personal projects, various forms of beliefs, behaviours, attitudes, values, interests, skills, standards, learning, etc. are internalized and categorized as a result of adjustment strategies specifically tailored to equally specific contexts (Krumboltz, 2011; Lahire, 2001; Lent, Brown, \& Hackett, 2000; Savickas, 1999).

Various research was conducted in recent years with students enrolled in vocational education and training study programs in Quebec (MELS, 2007; Molgat, Deschenaux, \& LeBlanc, 2011; Rousseau, Théberge, Bergevin, Tétrault, Samson, Dumont, \& MyreBisaillon, 2010; Savoie-Zacjc, Dolbec, Desjardins, \& Zniber, 2007). Most of the research focused on identifying the motivational factors for such an undertaking. However, few of the studies truly sought to identify the reason, rationale and reflection - in short, the underlying logic that elucidates a set of factors, criteria and motivations guiding the decision to pursue a vocational education and training program in Quebec, specifically from age $25 \mathrm{on}$. In this paper, we propose identifying the decisional logic underlying decision-making, resulting from biographical and interactionist tensions, of a majority of these individuals.

\section{Method}

The data analyzed stemmed from a research project aimed at enumerating and presenting the types of paths of young people enrolled in VET in secondary school in Quebec and in Ontario (Canada), as well as how the paths are constructed, in addition to identifying and describing the various forms of support, the perception of the youth enrolled in VET and how they integrate the support into their life paths. This data was collected 
during the winter of 2012 from students enrolled in a VET program for at least three months. Questions from a 90-minute semi structured biographical interview focused on the academic, professional, relational/matrimonial and residential dimensions of the path, as well as the perceptions and integration of support received on their life path, representations of the geographic and socioeconomic context, and their perspectives for the future.

Participants were selected on the basis of three criteria (site, gender and age), providing a non-probabilistic sample with a reasoned choice of an objective (Pirès, 1997). The sample includes 80 students enrolled in a vocational studies program in one of four training centers that participated in the study. More specifically for this article, we selected 30 participants age 25 and over. There were 18 women and 12 men enrolled in a wide variety of programs.

The research interviews were subsequently transcribed and then codified by research assistants to divide the data set into sections from the interview guide. Regarding this paper's objective, sections relative to the decision-making process of the young adults met with were selected for analysis (choice of VET program, relation to the school, academic aspirations and projects, professional aspirations and projects, relation to work). A thematic analysis (Paillé \& Mucchielli, 2012) was applied to the data set in a moderate inductive logic (Savoie-Zajc, 2004), conducted using QSR Nvivo 10 software. The data was organized according to theme by the two researchers and authors of this paper, first individually, then collaboratively. Next, an open analysis grid developed from the identified themes and allowing the emergence of new themes, as well as testing the predefined framework, made it possible to address the data. Various decision-making rationales, non-exclusive, were also identified, which had to be present in almost all of the participants in order to be selected.

The excerpts presented to support the themes described were reported in French, then translated into English for purposes of this paper. The participants linked to the selected excerpts are identified by their age, sex, and professional field.

\section{Findings}

The analysis of data identified five decision-making rationales: 1) Get out of a socioprofessional and economic slump; 2) Know yourself better, personally and socially; 3) Value the concrete and the practical; 4) Take advantage of supporting conditions; and 5) Reconcile proximity and the known. Table 1 indicate the number of participants who reported reflections and thoughts about on each decision-making rationales on two or more occasions.

\subsection{Get out of a Socioprofessional and Economic Slump $(n=26)$}

A first decision-making rationale shared by the vast majority of participants relates to a life path (personal, academic, professional, familial, relational) marked by difficulties and trials from which they more or less desperately seek to escape by pursuing studies. This rationale manifests itself in the outlines of a project not yet necessarily fully formed 
Table 1: Number of participants reporting reflections and thoughts about each decisionmaking rationales

\begin{tabular}{l|l} 
Decision-making rationales & N \\
\hline Get out of a socioprofessional and economic slump & 26 \\
\hline Know yourself better, personally and socially & 28 \\
\hline Value the concrete and the practical & 20 \\
\hline Take advantage of supporting conditions & 28 \\
\hline Reconcile proximity and the known & 28 \\
\hline
\end{tabular}

or in adjustment strategies to difficult living contexts. Many participants recount their parents' low level of education, as well as their parents' often negative attitude toward school: "It wasn't really valued there [...], I never had a discussion like: 'What do you plan to do after school?"” (Women, 32, Computer graphics)1․ "[...] Of course you can't do homework with your child when you yourself can't read or write. Because my mom, she doesn't know how to read or write." (Men, 33, Building mechanics). In other cases, the parents' educational level is not fully known, which implies a limited history of discussion about education: "He (father) wanted to work as soon as possible [...], that's why he didn't finish school [...] My mom, I don't know if she finished secondary school [...] We're not, how can I put it, we're not big on higher education." (Women, 26, Electricity). It should be noted that more than half of the participants have experiences marked by academic and pychosocial difficulties: dropping out, changing schools, behavioural and learning problems, drugs and poverty.

At the end of school there is a professional transition full of difficulties, frustrations and dissatisfactions: social benefits, depressive episodes, layoffs, poverty and social exclusion, difficulties meeting financial responsibilities, inability to pay for goods and services, atypical work conditions and schedules, etc. The decision and the commitment to pursue the path of VET studies are often preceded by a moment of general observation on the emptiness of their existence: "I wasn't on the right track, I had kind of a crooked track," (Women, 31, Computer graphics). "I'm tired of those places. I wanted something quieter, and I have an artistic side that I wanted to develop," (Women, 25, Aesthetics). Some of the participants may be an exception to these negative experiences: "I was encouraged to go to school but never had anyone to tell me that 'you don't have a choice, you're going to go,' and I think it's fine like that. I'm proud of my path anyway," (Women, 27, Secretarial studies).

\footnotetext{
${ }^{1}$ Note that some of the programs mentioned in the results are only offered in French and therefore we propose a literal translation of the name.
} 


\subsection{Know Yourself Better, Personally and Socially $(\mathrm{n}=28)$}

This second rationale, which largely results from the storyline of one's life path up to now, is based on a motivated statement of personal commitment to see yourself as stronger and more solid, but also - sometimes above all - in relation to the needs and expectations of employers and the job market. In a way, it is an opportunity to envision yourself differently, using adjustment strategies to increase your power with regard to oppressive contexts, a willingness to modify the trajectory of your path. Analysis of the interviews suggests a shared need to increase self esteem by obtaining a diploma to access the job market: "To have my diploma in hand, be proud of myself [...] then to find myself in a place where I'll feel good. I'm going to do what I like, then people will respect me," (Women, 31, Computer graphics); "I've come to realize that basically, you do your job your whole life [...] when you do something you like it makes all the difference, and it's reflected in everything." (Women, 34, Pastry making); "Developing different visions, trying to find jobs [...] and job security, for your family and for yourself," (Men, 33, Building mechanics).

In participants' comments there are often personal injunctions, i.e. an obligation to act, to get moving, to be worthy in one's own eyes. This is signaled by the words "have to" or "should," as motivation based on a sense of duty to oneself: "Maybe I should do something [...] It's time that I really do something now!" (Men, 27, Computing support); "I told myself that if I want to go farther than that in life ... I don't have a choice, I have to go back to school [...] It has to be something that I'm passionate about," (Women, 34, Pastry making); "I have to take care of my professional life, because I can't depend on anyone," (Women, 39, Carpentry). For others, this sense of duty toward self is directed toward their children, the importance of being proud of oneself in another's eyes: "I wanted to get it, so I could tell my daughter that even during severe trials when things go wrong, if I had given up ... I'm talking about it and it still affects me [...]. In my case, I did it for my daughter," (Women, 39, Carpentry).

Nearly all of the participants look at continuing education in VET as a place to develop interests and skills related to their values, but also as a step in a project, a fairly welldefined plan for professional life: "I'd really like to open my own business, I have an image in my head [...] it's certain that with the classes [...] a sort of little coffee and pastry shop," (Women, 34, Pastry making); "Later, I intend to take the assistant nurse course [...], to give myself some drive," (Women, 25, Aesthetics). Finally, harmonizing the present in school with a satisfying work transition is often inscribed on a path of interests, habits or hobbies from childhood to adolescence: "I play games a lot, I like building houses, why wouldn't I come to take the classes?" (Men, 25, Residential and commercial drafting); "I already know it, I already learned by myself [...] I came here more to improve myself," (Women, 32, Computer graphics).

\subsection{Value the Concrete and the Practical $(n=20)$}

This third rationale concerns the desire to identify a training project that can best be adapted to their learner characteristics, and to learning conditions and contexts to help 
them achieve a school-to-work transition and integration more quickly. Many of these students seem to have common characteristics in terms of valuing concrete and practical learning activities. They clearly affirm favouring an active and varied learning context: "I don't like monotonous, routine jobs [...] you know, you can do a little bit of anything, you never do the same work all the time $[\ldots]$ an active girl $[\ldots]$ who needs to move [...] to keep me awake [...]," (Women, 26, Electricity). Add to that the search for different types of tasks, but with a specific purpose: "I need something more concrete, more stable, that'll help me reach my goals," (Women, 26, Electricity).

The participants are also interested in - even anxious about - their VET classes leading to a rapid job integration, with advantageous conditions and prospects: "I chose electricity simply because they said that it pays a lot of money and that there weren't going to be enough electricians, that there'd be a lot of work in the field," (Women, 27, Electricity). There are some participants who have doubts or reservations about expected conditions and prospects: "Often they'll hire somebody who has a DVS because they can pay them less-like it or not-because it's not as much schooling," (Women, 30, Computer graphics).

One of the most important subthemes from the analysis of interviews concerns the choice of VET, through a process of comparison to the opportunity of higher education at college or university. It is the form of VET studies that is often favoured over that of higher education. To begin with, one seeks a shorter period of studies: "I'm going for a DVS that's going to be less long, but still with good opportunities," (Women, 27, Electricity); "I respect people who go to college (CEGEP) then university [...] for me, it's easier to get a DVS," (Women, 31, Computer graphics). It is also a question of classes more directly related to the trade activities in vocational education and training, without the addition of mandatory classes in a higher education program: "I did a session at college in multimedia, but philosophy and literature weren't for me at all," (Women, 31, Computer graphics); "I didn't want to go to college because there were too many classes that didn't interest me like philosophy and that other stuff. I really wanted to concentrate on a trade when I got out of school, to have my trade and then get in the job market," (Men, 26, Retail butchery); "You don't need, like at college, to take 55 more classes to get what you want!" (Men, 27, Computing support). Nevertheless, for some participants, the choice of a program specifically offered in VET is strictly based on a preference for content and not form: "A college diploma in computer science didn't interest me [...] Computer graphics is a little bit of graphics and a little bit of computing - it was like the best of both worlds," (Women, 30, Computer graphics).

Finally, there are some students for whom VET was the only educational destination realistically considered: "Since I was little, my mom knew it, my whole family knew it, then during all of secondary I told myself: 'No, college isn't for me, it's going to be vocational, it's going to be bing bang boom and done with,"' (Women, 28, Carpentry); "I would have liked [to go to college], because when I was little, I wanted to be a social worker, I would like to be a foster family. But then it was like going back to school to do my secondary before going to college. No [...] No, it was out of the question," (Women, 39, Carpentry). Few of the participant's view VET negatively or, in the same vein, devalue their own ability to learn: "In any case, I'm not enough of a nerd to enroll 
[...] in university. So I was okay with vocational education and training," (Women, 25, Secretarial studies).

\subsection{Take Advantage of Supporting Conditions $(\mathrm{n}=28)$}

This fourth rationale concerns the role of relationships and of social and institutional structures that act as contextual forces that facilitate or impede the pursuit of a professional project. Participants are not only "influenced" by social structures and relationships, they may also be the source of change through their own initiatives in relation to them: "I found out about the best places, basically the best schools that gave the program and it was really in Abitibi-Témiscamingue that it was rated best. [...] Given the fact that I'm from the region, it's sure that that attracted me even more," (Women, 26, Electricity); "When I heard about the course here, I said to myself, hey, I'll try to go here. So I enrolled here," (Men, 27, Computing support). In addition, there are personal, familial, financial and other issues related to their project: "When I was accepted, I jumped at the opportunity [...] I wanted to pay for my things as fast as possible. I didn't want to wait another year," (Men, 25, Residential and commercial drafting); "I had another car, that I sold to have a smaller model to be able, you know, to have some money [...] to buy all my material," (Women, 34, Aesthetics); "We were fed up [...] I left my job then I really wanted to concentrate on my studies [...] Getting up at 5 in the morning and starting to study an hour before the kid wakes up around 6 o'clock [...] Not always easy," (Men, 28, Electricity).

The success of a return-to-school project in VET for Quebec adults age 25 and over is based on the ability to mobilize and to take advantage of the support of significant people around them. This may be instrumental support provided by people more or less close to the students offering direct assistance, information and advice. The support could be information from people who have already completed the study program or gone to the training institution concerned: "A friend who did it, beauty care," (Women, 25, Aesthetics); "Someone who talked to me about Skills Outaouais because she took a program there. I checked it out [...], I read the requirements, the details and everything, and I was interested," (Men, 33, Building mechanics). The contribution of such information can transform lives when provided at the right time: "In secondary school, if I had known that there was a DVS in pastry-making [...]. That would have changed my life, I would probably have come to do the program," (Women, 34, Pastry making).

The vast majority consulted a career counselor in a community or government organization specialized in job development before formally committing to pursuing studies in VET. For some, it was a matter of getting help before making an informed decision: "I went to see a counselor, then with his help [...] we found that computer graphics would fit well with my personality [...] explaining to me what was really taught [...] I was able to make a more informed decision," (Women, 30, Computer graphics); "We did aptitude tests [...], we looked at trying out being a student for a day, we looked at Emploi-Quebec, we did the whole file [...] it was really amazing," (Women, 34, Pastry making). This counseling experience at this time of their life often contradicts that experienced with another such professional during secondary school a few years before: 
"I was told by a counselor that I would never do anything in life because I didn't have good grades and that I would never succeed in life, that I was a loser," (Women, 34, Pastry making).

In addition to instrumental support, the vast majority of participants attest to emotional support received from loved ones, encouragement and support in their activities: "No matter what I did in life, you know, they always supported me in what I did, and they never opposed me either, in my decisions, in my choices," (Women, 34, Aesthetics); "We went to see the doctor together and then basically after that we took some steps. From that point on I pulled myself together more and was able to go back to school," (Women, 30, Computer graphics). Material support affects the emotional sphere more, particularly the importance of qualifying professionally to be able to meet the social expectations of adult life: "For my mom, it was important that I have at least a secondary school diploma. She really encouraged me in that," (Women, 31, Computer graphics); "My mom who told me, 'As long as you haven't finished your secondary 5, don't think about anything else," (Men, 28, Electricity); "I have a deal with my mom [...] if I finish my program and find a job, after six months of working, she'll co-sign on a house for me," (Men, 25, Residential and commercial drafting). As for the father's role, it is often the same as the mother's, or perhaps more subdued. "My dad was glad too that I went back to school," (Men, 27, Computing support).

The support of spouses is essential. In some cases, the professional project of one is part of that of the other and in a broad sense falls within the couple's project: "My partner, he encourages me a lot, practically every day. When I'm kind of down, less positive, he's there to push me," (Women, 31, Computer graphics); "She encouraged me all the same [...] She went back to school, to Skills Outaouais in pharmaceutical studies, and now it's been seven years that's she's worked here in the region," (Men, 33, Building mechanics); "My ex criticized me: 'If you're not happy, why don't you change?' [...] That also pushed me to go back to school and change fields," (Men, 26, Retail butchery).

One the other end of the spectrum, there are behaviours that undermine the desire to pursue studies in VET: "For sure my parents were disappointed [...] I'm doing computer graphics even if it's maybe a lower level than college but ...," (Women, 30, Computer graphics); "My mom would really have liked me to continue school. [...] I know that my mom was really disappointed," (Women, 39, Carpentry); "I have an aunt who said that this here is not a real school. [...] According to her, if it's not university, it's not a real school. [...] My father is disappointed in me I think, because I'm not doing what he's doing," (Men, 25, Residential and commercial drafting).

Combining both instrumental and emotional aspects, modeling is another form of support present in some participants in the process leading to the decision to pursue studies in vocational education and training. Modeling can occur in terms of behaviours or of attitudes: "My uncle is a superintendent [...] he talked to me about the job, so that's what interested me. [...] He taught, he can really help me when there's a problem," (Women, 26, Electricity); "My grandmother [...] she went back to do her post-graduate degree, she was 60 years old and she went," (Women, 32, Computer graphics); "During the summer I worked with Serge and it was like, oh, that's what I 
want to do!" (Women, 39, Carpentry).

A last form of important support is financial support. Most of the participants are in a couple, with kids and regular expenses (housing, car, food, etc.). The question of financing studies, as well as other expenses of civic life, involves reasoned planning. Some students can always count on their parents, freeing them from some of these common obligations: "I still live with my parents, so I don't pay for housing or food, and I know that that helps me a lot," (Men, 28, Carpentry); "I only receive $\$ 1000$ a month. With my girlfriend's salary, that helps, but I still sometimes have to call mom or dad," (Men, 28, Electricity) Some of the participants receive income support from the state. In Quebec, it is possible to continue this support as part of a return-to-school project. However, the government has the right to approve or reject the educational project of applicants. Applicants must therefore demonstrate need to government officials. Sometimes the experience is easy, even helpful, and sometimes laborious: "I really fought [...] to get this aid, which was really hard to get," (Women, 34, Aesthetics); "I met an EmploiQuebec agent who directed me to the VET center, I chose a program [...] and I have the good fortune to be funded by Emploi-Quebec [...] the agent who was there told me: 'I'm going to send you to training, to get you a real diploma,"' (Women, 27, Secretarial studies); "They encourage us to go to school, they give us programs to help us and all, but they limit us down the line, then we're stuck [...] if you have a house that costs you $\$ 1500$ a month, and all the food, the car, the gas. How are you going to live on $\$ 800 ? "$ (Men, 33, Building mechanics).

For adults who return to school without support from parents or income support measures, the state offers a loan and bursary program. This can be a lifesaver for participants: "If I don't have the right to loans and bursaries, I can't go back to school, I have nothing," (Women, 39, Carpentry); "It's really serious, a damn good thing that it's there. The bursaries help me a lot [...], if I didn't have that, I wouldn't be able to go," (Women, 28, Carpentry). In addition to financial aid for school, some participants have to meet their needs with food aid: "I went to see the school social worker because I was having a hard time finding the money to eat. So she helped me a little [...]. After that, things got better," (Women, 25, Aesthetics); "I also go to Centre Bernard-Hamel for food every month [...] for those who don't have big salaries [...], that's helped a lot," (Men, 28, Electricity).

\subsection{Reconcile Proximity and the Known $(n=28)$}

The decision to return to school in vocational education and training may rely on this final rationale, that of seeking to reconcile proximity and the known. It is a sort of adjustment strategy to contextual forces, to bring important elements from other areas of one's life into the project. The vast majority of participants place considerable emphasis on pursuing education in their region, enabling them to save money on studies, transportation and other things, as well as travel time and distance. In some cases, this criterion may disqualify an inspirational study project offered in another region, prioritizing that considered less interesting, which favours proximity and the known: "I like my region. I won't say that I didn't think about going somewhere else, but I feel 
good here [...]. I'm close to my family, too. So I don't want to go away," (Women, 25, Aesthetics); "I arranged to find something that interested me enough that was offered in Rouyn. [...] I didn't want to move," (Women, 28, Carpentry); "I would have a hard time studying away from home [...] I'd probably miss my family [...]. I'm doing this program because I can stay in the area. I don't want to go to the big centers," (Men, 28, Electricity). For those who enroll in programs farther away, the experience is often seen more negatively: "It's an hour away and I have the kids so I have to organize everything in the morning [...] from daycare to school [...]. It's a lot of driving [...], a lot of organization, [...] sacrifices for coming to school," (Women, 34, Pastry making).

It is difficult to isolate the experience of continuing education in VET for participants age 25 and over from all other needs and roles in life. Moreover, an effort to reconcile these factors is undertaken both to prepare the return-to-school project and to complete it, in collaboration with loved ones and others concerned: "My son arrives home for lunch, and I'm there. [I can] also make my own schedule, be self-employed," (Women, 34, Aesthetics); "I wanted to go into multimedia at university [...] my girlfriend got pregnant $[\ldots]$. With a baby and everything at university, I would have cracked $[\ldots]$. My second choice was to take another program at the Polymétier in electricity, what I'm doing now," (Men, 28, Electricity); "Going back to school at my age, I find it hard. [... I'm a single parent. If I had help at home, maybe it would be easier. But you have to be at home, then in the morning before you leave you have to think of everything, see to everything," (Women, 39, Carpentry).

\section{Discussion}

The results of this thematic analysis from interviews with 30 Quebec adults age 25 and over enrolled in a VET study program resulted in five decision-making rationales that guided their career decision: 1) Get out of a socioprofessional and economic slump; 2) Know yourself better, personally and socially; 3) Value the concrete and the practical; 4) Take advantage of supporting conditions; and 5) Reconcile proximity and the known.

Both initial educational experiences (childhood, adolescence) and employment experiences are marked by problems and pitfalls, dissatisfactions and often humiliations. These findings are consistent with those of Lehman et al. (2014) and Vonthron et al. (2007) concerning the experience of difficulties - academic, social, professional, familial, psychological and others - that are more common among this population. In this respect, it seems that some of the students encountered present personal and social identities weakened by dysfunctional and unconstructive relationships with educational and employment institutions that bear standards, values, guidelines, ideologies, injunctions and directives as proposed in studies by Cohen-Scali and Pouvaud (2008), by Dumora et al. (2008) or by Lahire (2001). These sociorelational experiences, in addition to impacting the non-linearity of paths (Bessin et al., 2010; Peavy, 1997), are related to the career decision-making difficulties raised in Gati's work (Gati et al., 1996; Gati et al., 2010): the level of preparation (motivation, indecision, dysfunctional beliefs), information (on oneself and professions, and how information is gathered and processed) and 
representations (internal and external conflicts, incorrect information). The academic and professional contexts encountered on one's path, whether related to institutions or the influence of social relationships, have in some way shaped the representations, emotions or behaviours involved in the decision to return to school in vocational education and training, as seen in the works of Lent et al. (1994), Patton and McMahon (2006) and Peterson et al. (2002).

The pursuit of studies in VET for these adults is not so much a prolongation of the path as a redirection of the path. The notion of "adjustment" strategies is fundamental and especially meaningful for these people as they seek not only to adjust to contextual forces helping or hindering the present pursuit of a VET program, but do so in a transition, bifurcation or reconfiguration of their path, while trying out a new identity that is both personal and social (Elder, 1998). The relationship between contextual forces and adjustment strategies finds a major point of interaction in the role of supporters. Like students of all ages, participants may benefit from emotional, instrumental and financial support from loved ones such as parents, friends and teaching and professional staff from institutions and the outside (Burt, 2000; Cournoyer, 2012; Giordano, 2003; Granovetter, 1973). However, in comparison with previous studies on the role of social relationships on the academic paths of young adult populations (Cournoyer, 2008; Cournoyer, 2012; Cournoyer, Fortier, \& Deschenaux, 2017), three things play an important role: spouses, the state and guidance counselors. Spouses are more than mere emotional partners, they are also parental and financial partners. They come to replace the predominant role of parents, particularly mothers, as factors of exchange and influence. As for the state, it is an indispensable actor for participants receiving social benefits who want to maintain them while pursuing studies, rather than be faced with the obligation to look for a job without additional education. Therefore, the state, through its advisors/agents, is a donor to persuade and to satisfy in order to obtain the financial aid to pursue a project otherwise unachievable. Guidance counselors are often seen as mechanisms placed between the state and benefit recipients for obtaining financial assistance. However, the experience reported by the majority of participants suggests that at this point in their lives - perhaps more than at a younger age - the aid, advice and insight in terms of information about self and the job market, about making an informed career decision, is highly sought after and appreciated.

Finally, the project to continue education in VET is more often a "means" to organize and articulate, in a fairly short period (compared to higher education), without spending too much time or money (transportation, financing studies), without upsetting all the roles in life toward one "end," an outlook on life that is satisfying on personal, professional and family levels. In this regard and as in Fournier et al. (2008) and the OECD (2010), VET in Quebec is a favourable mechanism for qualification and access to employment for the greatest number of people. Our analysis of comments from adult participants age 25 and over with highly heterogeneous life paths (Deschenaux \& Roussel, 2010) suggests that the unfavourable prejudices attached to VET and reported by many authors (Lehmann, Taylor, \& Wright, 2014; MELS/Réseau des commissions scolaires, 2007) are of little concern to them. It can be argued that the needs for security and socioeconomic stability are, as Bujold and Fournier (2008) point out, sufficiently 
satisfied in these more experienced adults.

The decision-making logic of participants fits very well into the model of dual tension between life path and professional project, and between contextual forces and adjustment strategies. Consequently, decision-making processes, especially as related to careers, are interrelated to one another and part of a complex process involving resources and constraints (Charbonneau, 2005; De Coninck \& Godard, 1991; Shanahan, 2000) at once cognitive, emotional, behavioural, relational and contextual (Hodkinson \& Sparkes, 1997; Lent, Brown, \& Hackett, 1994; Patton \& McMahon, 2006; Peterson, Sampson, Reardon, \& Lenz; Saka \& Gati, 2007), but also historical (Edler, 1998), for the purpose of freedom and self-realization.

This research has some limitations. First, the proposed findings do not make it possible to distinguish differences in terms of gender or age brackets. It is also not possible to distinguish the decision-making rationales of these students age 25 and over from their colleagues under age 25 who take the same type of training, nor does it help to situate the realities experienced in Quebec compared to those of other Canadians. However, it is important to recall that the purpose of this article is to focus specifically on students age 25 and over. Considering the comprehensive paradigm adopted in this research, we did not seek to test the hypotheses in order to confirm relationships between the identified variables or components of decision-making. Finally, this research aimed to undertake a first exploration of decision-making logic with regard to a modeling of decision-making action resulting from the works of Cournoyer, Lachance and Samson (2016) and Cournoyer, Fortier and Deschenaux (2017). These limitations could nonetheless be taken into account for future research.

The findings and elements of discussion proposed in this paper may guide educational and psychosocial professionals working in vocational education and training centers, as well as social and institutional decision-makers, to establish support and supervisory measures for these older students in regard to their particular issues and realities. As in the works by Aubret and Demouge (2000) on lifelong learning, the decision-making logic uncovered should encourage educational institutions to consider individuals' professional orientation as a complex process of identity building, socialization and socioprofessional integration. Returning to school as an adult means reliving and re-experiencing one's relationship to studies, to school, and to oneself in terms of abilities. Beyond the strict mission of learning, it is important to help individuals integrate their educational experiences into a perspective of personal, professional and social development.

Regarding social policies related to vocational education and training, the students' personal, professional and social development objectives should align with the objectives to prevent job precarity and socioeconomic exclusion proposed by the Quebec government (Government of Quebec, 2017). An adult who attends vocational education and training is more than just a student. He is also a parent, a spouse, and a person with financial and familial responsibilities; in short, he is a person who wants to be accompanied in his studies and wants to find a job that will give him stability and security for himself and his family. In this regard, it seems appropriate to provide additional information and academic and professional counseling services. Adopting alternating training, such as that proposed by European models of continuous alternation between 
education and employment, could help to foster this faster, more concrete and practical link mentioned by participants in this research. Finally, promotion and enhancement of vocational education and training must continue to inform and potentially interest a greater number of students under age 20 (Hart, 2017), but it must clearly and realistically turn toward older students such as those concerned by this inquiry, through means that directly target their needs and aspirations as professionals, family members, citizens, etc. (Goyer, 2017). Among other things, it must reassure these adults in order to appease their doubts while raising their hopes. Returning to vocational education and training at age 25 or over in Quebec seems to be an experience that heals wounds of the past, reconciles roles in life up to the present, and is a quest for a more satisfying life in the near future. 


\section{References}

Aubret, J., \& Demouge, N. (2007). Orientation des adultes et formation tout au long de la vie, Savoirs, 4, 11-28.

Bart, D., \& Fournet, M. (2010). Le projet professionnel et personnel des étudiants, assise de leur professionnalisation? Revue internationale de pédagogie de supérieur, 26(1), 1-18.

Beaucher, C., \& Mazalon, E. (2003). Les projets: une prise en charge de l'avenir professionnel? Les élèves des métiers semi-spécialisés. Alinéa, 14, 25-44.

Bertaux, D. (2005). Le récit de vie. Paris: Armand Colin.

Berthoz, A. (2013). La décision. Paris: Odiles Jacob.

Bessin, M., Bidart, C., \& Grossetti, M. (2010). Bifurcations. Les sciences sociales face aux ruptures et à l'événement. Paris: La Découverte.

Bidart, C., Lavenu, D., \& Pellissier, A. (2005). Des jeunes, leurs amis, leurs parents: quelles relations, quelles évolutions? Rapport de recherche pour la Caisse nationale des allocations familiales.

Blesson, P. (2001). Étude des rapports entre projet et décision. L'Orientation scolaire et professionnelle, 30 (hors série), 228-233.

Bourdieu, P. (1980). Le capital social. Actes de la recherche en sciences sociales, 31, $2-3$.

Bourdieu, P. (1994). Raisons pratiques. Sur la théorie de l'action. Paris: Éditions du Seuil.

Bourdon, S., Charbonneau, J., Cournoyer, L., \& Lapostolle, L. (2011). Famille, réseaux et persévérance au collégial, Phase 2. Rapport de recherche. Sherbrooke: Équipe de recherche sur les transitions et l'apprentissage, Université de Sherbrooke.

Boutinet, J.-P. (2004). Que savons-nous sur cet adulte qui part en formation? Savoirs, $1(4), 9-49$.

Boutinet, J.-P. (2005). L'anthropologie du projet. Paris: Presses Universitaires de France.

Bosch, G., \& Charest, J. (2008). Vocational education and training and the labour market in liberal and coordinated economies. Industrial Relations Journal, 39(5), 428-447.

Brockmann, M., Clarke, L., \& Winch, C. (2008). Knowledge, skills, competence: European divergences in vocational education and training (VET) - the English, German and Dutch cases. Oxford Review of Education, 34(5), 547-567.

Bronfenbrenner, U. (1977). Toward an experimental theory of human development. American Psychologist, 513-531.

Bronfenbrenner, U. (1986). Ecology of the family as a context for human development: Research perspectives. Developmental Psychology, 22(6), 723-742.

Bujold, C., \& Fournier, G. (2008). Occupational representations of workers in nonstandard and precarious work situations. Journal of Career Assessment, 16 (3), 339-359.

Burt, R. S. (2000). The network structure of social capital. In R. I. Sutton et B. M. Staw, Research in Organizational Behavior (p. 385-423). Greenwitch, CT: JAI Press. 
Cacouault, M., \& Oeuvrard, F. (2001). Sociologie de l'éducation. Paris: La découverte. Charbonneau, J. (2005). La question des temporalités dans l'analyse du social. In D. Mercure (dir.), L'analyse du social: les modes d'explications (pp. 169-182). Quebec: Les Presses de l'Université Laval, collection «Sociologie contemporaine».

Conseil des ministres de l'éducation du Canada (2008). Education in Canada. Toronto, Canada: Conseil des ministres de l'éducation du Canada. Consulted online: http:// www.cmec.ca/Publications/Lists/Publications/Attachments/64/Education-in-Cana da2008.pdf

Conseil supérieur de l'éducation (2012). Pour une formation qualifiante chez les jeunes de moins de 20 ans. Lever les obstacles à la formation professionnelle au secondaire. Quebec: Conseil supérieur de l'éducation, Gouvernement du Quebec.

Cournoyer, L. (2008). L'évolution de la construction du projet professionnel de collégiennes et de collégiens lors des trois premiers trimestres d'études: le rôle des relations sociales. Thèse de doctorat. Sherbrooke, Canada: Université de Sherbrooke.

Cournoyer, L. (2012). Le rôle des relations sociales sur l'évolution des projets professionnels. In S. Bourdon et J. Charbonneau, Regard sur ... les jeunes et leurs relations. Quebec: Presses de l'Université Laval.

Cournoyer, L., Fortier, S. et Deschenaux, F. (à paraître, 2017). Dimensions traversant le processus décisionnel conduisant à la poursuite d'études formation professionnelle au Quebec et en Ontario: entre expériences passées et espoirs salvateurs. L'Orientation scolaire et professionnelle.

Cournoyer, L., \& Lachance, L. (2014). Le processus de prise de décision liée à la carrière chez des élèves de 4 e et de 5e secondaire de la Commission scolaire de Laval: rapport final. Université du Quebec à Montréal. Récupéré de http://fr.slideshare.net/louisc o/cournoyer-et-lachance-2014-le-processus-de-prise-de-dcision-relative-la-carrire-fin al

Cournoyer, L., Lachance, L. et Samson, A. (2016). L'action décisionnelle de carrière: processus en deux dimensions, quatre tensions. Dans J. Masdonati et L. M.C. Bangali (dir.). Éducation et vie au travail: Arrêt sur image! Perspectives contemporaines sur les parcours d'orientation des jeunes (pp. 119-148). Quebec: Presses de l'Université Laval.

Coslin, P.G. (2012). Psychologie de l'adolescent. Paris: Armand Colin.

De Coninck, F., \& Godard, F. (1991). Les stratégies temporelles des jeunes adultes. In T. Blöss and I. Feroni (dir.), La socialisation de la jeunesse, Enquête. Cahiers du CERCOM, 6. Consulted online: http://enquete.revues.org/sommaire14.html

Degenne, A., \& Lebeaux, M.-O. (2004). The dynamics of personal networks at the time of entry into adult life. Social Networks, 27(4), 337-358.

Deschenaux, F., \& Roussel, C. (2010). De la pratique à l'enseignement d'un métier en formation professionnelle au Quebec: un passage volontaire. Pensée plurielle, 24(2), 131-143.

Deschenaux, F., \& Laflamme, C. (2009). Réseau social et capital social: une distinction conceptuelle nécessaire illustrée à l'aide d'une enquête sur l'insertion professionnelle de jeunes Québécois. SociologieS [En ligne]. Récupéré de http://sociologies.revues .org/index2902.html 
Doray, P., Bélanger, P., \& Mason, L. (2005). Entre hier et demain: carrières et persévérance scolaires des adultes dans l'enseignement technique. Lien social et politiques-RIAC, 54, 75-89.

d'Ortun, F. (2009). La persévérance jusqu'au diplôme du secondaire des 16-24 ans inscrits en zones urbaine et rurale dans les centres de formation générale aux adultes, in N. Rousseau (dir.), Enjeux et défis associés à la qualification. La quête d'un premier diplôme d'études secondaires (pp. 77-100). Quebec: Presses de l'Université du Quebec.

Dumora, B., Aisenson, D., Aisenson, G., Cohen-Scali, V., \& Pouyaud, J. (2008). Les perspectives contextuelles de l'identité. L'orientation scolaire et professionnelle, $37(3), 387-411$.

Dupuy, R. (1998). Transitions et transformation des identités professionnelles. Le cas des adultes en situations de formation continue. In A. Baudion-Broye (dir.), Événements de vie, transitions et construction de la personne (pp. 45-72). Saint-Agne, France: Éditions Érès.

Elder, G. H. (1998). The life course and human development. In R. M. Lerner (dir.), Handbook of Child Psychology. Volume 1: Theoretical Models of Human Development (p. 939-991). New York: Wiley and Sons.

Fournier, G., Lachance, L., \& Bujold, C. (2009). Nonstandard career paths and profiles of commitment to life roles: A complex relation. Journal of Vocational Behavior, $74(3), 321-331$.

Gati, I., Krausz, M., \& Osipow, S. H. (1996). A taxonomy of difficulties in career decision making. Journal of Counseling Psychology, 43(4), 510.

Gati, I., Landman, S., Davidovitch, S., Asulin-Peretz, L., \& Gadassi, R. (2010). From career decision-making styles to career decision-making profiles: A multidimensional approach. Journal of Vocational Behavior, 76(2), 277-291.

Giordano, P. C. (2003). Relationships in adolescence. Annual review of sociology, 29, $257-281$.

Government of Quebec (1988). Education Act. Quebec: Government of Quebec.

Government of Quebec (2017). Basic vocational education and training regulation. Last update: May 1, 2017. Quebec: Government of Quebec.

Goyer, L. Landry, C. and Leclerc, C. (2008). Enjeux de la mise à l'essai du bilan des acquis relatifs à la formation générale de base: points de vue des personnes conseillères. Direction de la formation générale des adultes du Ministère de l'éducation, du loisir et du sport (MELS)/Centre de recherche et d'intervention sur l'éducation et la vie au travail (CRIEVAT), Laval University, Quebec City, Quebec.

Goyer, R. (2017). Promouvoir la formation professionnelle autrement. Bulletin de l'Observatoire Compétences-Emplois, 8(1). Consulted online: http://www.oce.uq am.ca/article/promouvoir-formation-professionnelle-autrement/

Granovetter, M. S. (1973). The strength of weak ties. American Journal of Sociology, $78(6), 1360-1380$.

Hart, S.A. (2017). Mot de la rédaction. Bulletin de l'Observatoire Compétences-Emplois, 8(1). Consulted online: http://www.oce.uqam.ca/article/promouvoir-formationprofessionnelle-autrement/ 
Grote, G., \& Hall, D. T. (2013). Reference groups: A missing link in career studies. Journal of vocational behavior, 83(3), 265-279.

Hodkinson, P., \& Sparkes, A. C. (1997). Careership: a sociological theory of career decision making. British Journal of Sociology of Education, 18(1), 29-44.

Krahn, H., \& Taylor, A. (2005). Resilient teenagers: Explaining the high educational aspirations of visible-minority youth in Canada. Journal of International Migration and Integration, 6(3-4), 405-434.

Krumboltz, J. D. (2011). Capitalizing on happenstance. Journal of Employment Counseling, 48(4), 156-158.

Lahire, B. (2001). L'homme pluriel. Les ressorts de l'action. Paris: Nathan.

Lent, R., Brown, S., \& Hackett, G. (1994). Toward a unifying social cognitive theory of career and academic interest, choice, and performance. Journal of Vocational Behavior, 45(1), 79-122.

Lent R.W., Brown, S.D., \& Hackett, G. (2000). Contextual supports and barriers to career choice: A social cognitive analysis, Journal of Counseling Psychology, 47(1), $36-49$.

Lehmann, W., Taylor, A., \& Wright, L. (2014). Youth apprenticeships in Canada: On their inferior status despite skilled labour shortages. Journal of Vocational Educational \& Training, 66(4), 572-589.

Lhotellier, A. (2003). L'accompagnement: tenir conseil. Carriérologie, 9(1), 25-61.

Ministère de l'éducation (1997). L'école, tout un programme. Énoncé de politique éducative. Quebec: Government of Quebec.

Ministère de l'Éducation (2002). Government Policy on Adult Education and Continuing Education and Training. Quebec: Government of Quebec.

Ministère de l'éducation, de l'enseignement supérieur et de la recherche (2015) Inscriptions par programme de formation professionnelle. Quebec: MEESR.

Ministère de l'éducation, du loisir et du sport. (2007). Des jeunes en chemin vers la formation professionnelle: Parcours et motivations. Quebec: Gouvernement du Quebec. Consulted online: http://www.mels.gouv.qc.ca/fileadmin/site_web/docum ents/dpse/JeunesCheminFP_Rapport.pdf

Ministère de l'éducation, du loisir et du sport. (2010). La formation professionnelle et technique au Quebec. Un aperçu. Quebec: Gouvernement du Quebec.

Ministère de l'Éducation, du Loisir et du Sport du Quebec (2009). I care about school! All together for student success. Action Strategy. Quebec: Government of Quebec.

Ministère de l'éducation, de l'enseignement et de la recherche du Quebec (2015). Nombre d'inscriptions par programme de formation professionnelle, selon le type de diplôme recherché, le secteur de formation, le sexe, le type de fréquentation scolaire, la langue d'enseignement, la strate d'âge et le statut d'élève débutant, année scolaire 20132014. Quebec: MEERQ.

Ministère de l'Éducation et de l'Enseignement supérieur (2017). Policy on Educational Success. Quebec: Government of Quebec.

Molgat, M. (2007). Do transitions and social structures matter? How 'emerging adults' define themselves as adults. Journal of Youth Studies, 10(5), 495-516. 
Niewiadomski, C., \& Delory-Momberger, C. (2013). La mise en récit de soi. Place de la recherche biographique dans les sciences humaines et sociales. Villeneuve d'Asq: Septentrion.

Organisation de coopération et de développement économiques. (2010). Les Clés de la réussite: Impact des connaissances et compétences à l'âge de 15 ans sur le parcours des jeunes canadiens. Paris: OCDE.

Paillé, P., \& Mucchielli, A. (2012). L'analyse qualitative en sciences humaines et sociales. Paris: Armand Colin.

Patton, W., \& McMahon, M. (2006) The systems theory framework of career development and counseling: Connecting theory and practice. International Journal for the Advancement of Counselling, 28(2), 153-166.

Peavy, V. (1997). SocioDynamic counselling: A constructivist perspective. Victoria, Canada: Trafford.

Peterson, G. W., Sampson Jr, J. P., Lenz, J. G., \& Reardon, R. C. (2002). A cognitive information processing approach to career problem solving and decision making. Career Choice and Development, 4, 312-369.

Peterson, G. W., Krumboltz, J. D., \& Garmon, J. (2005). Chaos out of order: New perspectives in career development in the information society. Issues in Career Development, 53-80.

Pirès, A. (1997). Échantillonnage et recherche qualitative: essai théorique et méthodologique. In J. Poupart, J.-P. Deslauriers, L.-H. Groulx, A. Laperrière et R. Mayer (dir.), La recherche qualitative. Enjeux épistémologiques et méthodologiques (pp. 113-169). Montréal: Gaëtan Morin Éditeur.

Rousseau, N., Théberge, N., Bergevin, S., Tétreault, K., Samson, G., Dumont, M., \& Myre-Bisaillon, J. (2010). L'éducation des adultes chez les 16 à 18 ans: La volonté de réussir l'école... et la vie. Éducation et francophonie, 38(1), 154-177.

Saka, N., \& Gati, I. (2007). Emotional and personality-related aspects of persistent career decision-making difficulties. Journal of Vocational Behavior, 71 (3), 340-358.

Savickas, M. L., Nota, L., Rossier, J., Dauwalder, J. P., Duarte, M. E., Guichard, J., Soresi, S., Van Esbroeck, \& Van Vianen, A. E. (2009). Life designing: A paradigm for career construction in the 21st century. Journal of Vocational Behavior, 75(3), 239-250.

Savickas, M. L. (1999). The transition from school to work: A developmental perspective. The Career Development Quarterly, 47, 326-336.

Savoie-Zajc, L. (2004). La recherche qualitative/interprétative en éducation. In T. Karsenti et L. Savoie-Zajc (dir.), La recherche en éducation: étapes et approches (pp. 123-150). Sherbrooke: Éditions du CRP.

Savoie-Zajc, L., Dolbec, A., Desjardins, L., \& Zniber, A. (2007). La réussite scolaire d'étudiants adultes inscrits dans des programmes de formation professionnelle: enjeux, défis. Rapport de recherche. Quebec: Ministère de l'Éducation, du Loisir et du Sport (MELS). Consulted online: http://www.frqsc.gouv.qc.ca/upload/editeur/ RF-LorraineSavoie\%282\%29.pdf

Shanahan, M. J. (2000). Pathway to adulthood in changing societies: Variability and mechanisms in life course perspective. Annual Review of Sociology, 26, 667-669. 
Valach, L., Young, R. A., \& Michel, K. (2003). Counselling for vocational career and life projects: Action conceptualisation. AIOSP International conference, Quality development in vocational counselling and training: International conference held in Bern (Switzerland) from September 3 to 9, 2003. Consulted online: http://www. svb-asosp.ch/kongress/data/docs/valach_01.pdf

Vondracek, F., \& Reitzle, M. (1998). The viability of career maturity theory: A developmental-contextual perspective. The Career Development Quarterly, 47(1), $6-15$.

Vonthron, A. M., Lagabrielle, C., \& Pouchard, D. (2007). Le maintien en formation professionnelle qualifiante: effets de déterminants motivationnels, cognitifs et sociaux. L'orientation scolaire et professionnelle, 36(3), 401-420. 


\section{Biographical Notes}

Dr Louis Cournoyer is a professor in career counseling at the Université du Quebec à Montréal. His researches focuses on the career decision-making processes of young people and adults, social relations influences on career pathways, and educational and professional trajectories.

Dr Frédéric Deschenaux is currently Dean of studies at the Université du Quebec à Rimouski. As a sociologist of education, his research focuses on educational and professional backgrounds of VET students and methodologies in the social sciences and techniques of qualitative data analysis. 